\title{
Curcumin- Extraction, Physical and Chemical Analysis, Formulas and Control. Basic Methods for Further Research
}

\author{
ELENA NICULET ${ }^{1}$, GINA VICA NECULIA ${ }^{2}$, ALIN LAURENTIU TATU ${ }^{1}$, OLIMPIA DUMITRIU BUZIA ${ }^{1 *}$ \\ 'Dunarea de Jos University of Galati, Faculty of Medicine and Pharmacy, Unit Research Center in the field of medical and \\ pharmaceutical sciences Dunãrea de J os, Pharmacology Sciences Department, 35 Al. I. Cuza Str., Galati, Romania \\ ${ }^{2}$ College of Pharmacists Galati, 156A Brailei Str. 800367, Galati, Romania
}

\begin{abstract}
Turmeric, with its active component curcumin has been regarded latelyas an important potential therapeutic agent due to its properties and many uses. Further research needs to be done both on animals and humans in order for it to be used at a large scale. As curcumin gets absorbed better through topical and not oral administration, curcumin-based pharmaceuticals with skin passage must be devised. In order for this to be done, the need for a standardized, verified and simple extraction method and one for ointment preparation with stability in time rises. We propose in this study a method for curcumin extraction, one that ensures an adequate stability in time and a method for pharmaceutical control.
\end{abstract}

Keywords: turmeric, curcumin, extraction, ointment, alaysis

Since ancient times people have studied nature and plants inherently concerning their healing effect on the human body. Plants have been considered indisputable curative means-natural remedies for humans and animals.

Researchers have sought after their bio-properties, bioavailability, possible interactions, adverse effects, their pharmacological uses or their efficacy and safe use both in animals or human subjects.

Turmeric is one of the many plants with a multitude of beneficial health -properties which nature makes available for people. Besides its use as a condiment or pigment, turmeric, a source of curcumin, has been used with medicinal purpose in India (Curcuma longa) for centuries. Proof that curcumin has anti-inflammatory and anticarcinogenic activity has renewed the scientific interest concerning disease prevention and treatment.

Curcumin is the main natural polyphenol found in the rhizome of Curcuma longa (turmeric), having antioxidant, anti-inflammatory, antimutagenic, antimicrobial, antiparasitic and anticancerous properties.

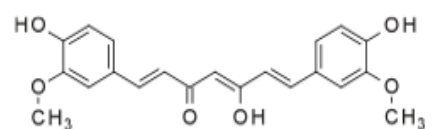

Enol form

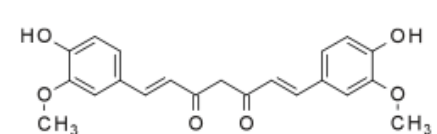

Ceto form
Administered orally, curcumin has low bioavailability due to the fact that it is poorly absorbed by the gastrointestinal system. As a topic, this polyphenol is better absorbed and it is such used in various skin diseases -inflammation and lesions.

The wide number of diseases in which curcumin acts as a therapeutic agent is a direct result from its various pharmacological properties: antioxidative, antiinflammatory, anticarcinogenic, antimutagenic, antiproliferative, anticoagulant, antiviral, antibacterial, antifungal, antiprotozoal, antidiabetic, hypotensive, hypocholesterolemic, UV protective, wound healing, choleretic, antifertility, antifibrotic, antiulcerative or antivenomous[1-8]. One needs to emphasize the fact that synthetic drugs (such as tetracycline, hydrochlorothiazide, statins, NSAIDS, beta blockers or topical steroids) have systemic and cutaneous toxic pharmacological side effects and that secondary Staphyloccocal or other types of infections can occur on the skin (with unnecessary cutaneous microbioma or incipient lesion changes) or in any other organ[9-37].
The main objective of our research was to obtain curcumin-based pharmaceuticals. Concerning the pharmaceutical manufacturing, we extracted curcumin from Curcuma longa, made the physical and chemical analysis of the extracted formula and finally realized the quality control of the pharmaceutical form.

\section{Experimental part \\ Materials and methods}

When extracting the active compounds from various animal or vegetable products with the help of a solvent, with or without the following step of concentrating the extracted compound (liquid, soft or solid states), the procedure must take notice of the nature of the drug to be extracted, of the active compounds that it contains, the chemical structure of the active principles that determine the solubility in various solvents and its heating stability.

The chosen method of extraction is the continuous one which takes place with the help of the Soxhlet apparatus composed from a balloon, an extraction body and an ascendant refrigerant, all of them linked together. This method was chosen due to the following advantages that it presents itself with: the lack of necessity for filtration, a lower quantity of solvent used (lower than in maceration) and it is a continuous process.

The selected solvent chosen for the component extraction from turmeric is introduced in the balloon and it is placed in a water bath. The extractor is attached over the balloon with the help of a rubber plug sealed off with collodion. A cartridge with the solid substance is imbedded in the extractor. This cartridge is made up from filter paper and the substance gets triturated before being introduced in it. Before introducing it in the extractor, the cartridge is weighed with the help of the analytical balance. The position of the cartridge needs to be precise so as itwill not surpass the level of the siphon. The refrigerant is mounted over the extractor and the connection to the water source is made. The solvent is heated and its vapors get to the refrigerant - here they cool off and condense; from here they flow out in the extractor, over the cartridge. The condensation level rises and as it does, the intended extraction of the compound from the solid takes place. When the liquid from the extractor reaches the superior side of the siphon, this starts and the solvent with the extracted component get transferred into the balloon. By continuing the heating process, new vapors of solvent reach the refrigerant - they follow the process and new quantities 
of extracted component are taken over by the solvent. Again, when the level of the siphon is reached, the liquid from the extractor goes in the balloon. After every cycle of extraction the solvent is enriched with the extracted component. 10 to 15 cycles later, the presence of the extracted component needs to be verified in the solvent from the extractor. If the component to be extracted is no more, the heating is stopped, the installation gets to cool off (the water circuit functions during this step of the procedure), the cartridge is taken out, it is dried and weighed. The difference between the initial mass and the final mass of the cartridge represents the quantity of substance extracted from the solid mass (the component). By knowing the quantity of substance introduced in the cartridge, the percent of the component extracted from the solid material can be calculated. The extraction is considered to have been done in total, having 8 to $9 \mathrm{~h}$ duration.

The spectrophotometric analysis done by absorption is used to identify the substance, its purity degree and the titration, based upon the property of the substance to selectively absorb electromagnetic radiations. The materials and apparatuses used for this technique are: ethanol, ethanol extract, test tubes, quartz dishes, Spekol 11 spectrophotometer and pure curcumin and they were used as such: the apparatus was standardized, the samples were introduced in the quartz dishes and these in their special base and the absorbance was registered at the necessary wavelengths.

Three variants of ointments were formulated: a lipophilic one, a hydrophilic one and one emulsion-type A/U, in which we added our extracted solution $(0.16 \mathrm{~g} \%)$ as stated in table 1.

Table 1

OINTMENT PREPARATION

\begin{tabular}{|l|c|c|c|}
\hline Components & Ointment 1 & Ointment 2 & Ointment 3 \\
\cline { 2 - 4 } & \multicolumn{3}{|c|}{ Quantities } \\
\hline Vanolin & lg & $7.83 \mathrm{~g}$ & - \\
\hline Cetaceum & - & $3 \mathrm{~g}$ & - \\
\hline Cholesterol & - & $2.95 \mathrm{~g}$ & - \\
\hline Olive oil & - & $1.46 \mathrm{~g}$ & - \\
\hline Alcohol extract & $0.08 \mathrm{~g}$ & $0.08 \mathrm{~g}$ & $0.08 \mathrm{~g}$ \\
\hline Corn starch & - & - & $3.5 \mathrm{~g}$ \\
\hline Nipagin & - & - & $0.09 \mathrm{~g}$ \\
\hline Nipasol & - & - & $0.01 \mathrm{~g}$ \\
\hline Glycerin & - & - & $46.5 \mathrm{~g}$ \\
\hline Distilled water & - & $25 \mathrm{~g}$ & $3.5 \mathrm{~g}$ \\
\hline
\end{tabular}

The quality control of the ointments was done - their homogeneity, color, smell, pH determination (with the help of the $\mathrm{pH}$-meter), adhesion capacity (Ojeda -Arbussa method), penetrating determination (in a Berzelius glass was an amount of ointment and from a fixed height a glass measuring baguette fell -with known dimensions and weight; the length of the portion that penetrated the mass was noted). When stability was determined we kept the samples at cold, hot and room temperatures, in the light and in the dark with the help of a lid box in which $5 \mathrm{~g}$ of sample are introduced and are held in the aforementioned conditions for 15 and 30 days [38-42].

\section{Results and discussions}

The extraction of curcumin from turmeric powder (Curcuma longa) was done with the help of the materials and the exact steps of the extraction technique described earlier. After the extraction ( $9 \mathrm{~h}$ duration), from $10 \mathrm{~g}$ of turmeric powder and 150 milliliters of ethanol, 17 milliliters of alcoholic extract were obtained. The solution was clear, orange, and it smelled like curcumin and ethanol; it was used for spectrophotometric analysis and ointment preparation.

First it was necessary to obtain the standardized scale from $10 \mathrm{mg}$ of curcumin dissolved in $100 \mathrm{~mL}$ of ethanol (100 $\mu \mathrm{g} / \mathrm{mL}$ ) from which $0.1-0.5 \mathrm{~mL}$ were pipetted and diluted up until $10 \mathrm{~mL}$ with ethanol $(1-5 \mu \mathrm{g} / \mathrm{mL})$. The spectrophotometric analysis was done by measuring the absorbance of this substance at $422 \mathrm{~nm}$ wavelength. Table 2 presents the results of this analysis, along with figure 1.

\begin{tabular}{|l|l|}
\hline $\begin{array}{l}\text { Concentration } \\
(\mu \mathrm{g} / \mathrm{ml})\end{array}$ & $\begin{array}{l}\text { Absorbance } \\
\text { (at } \mathbf{4 2 2} \mathbf{~ n m})\end{array}$ \\
\hline $\mathbf{l}$ & 0.160 \\
\hline $\mathbf{2}$ & $0.324^{-}$ \\
\hline $\mathbf{3}^{-}$ & 0.483 \\
\hline $\mathbf{4}$ & 0.651 \\
\hline $\mathbf{5}$ & 0.831 \\
\hline & $\mathrm{y}=0.1734 \mathrm{x}-0.0$ \\
\hline
\end{tabular}

\section{Table2}

CONCENTRATION AND ABSORBANCE OF THE SOLUTION SAMPLES FOR STANDARDIZED CURCUMIN

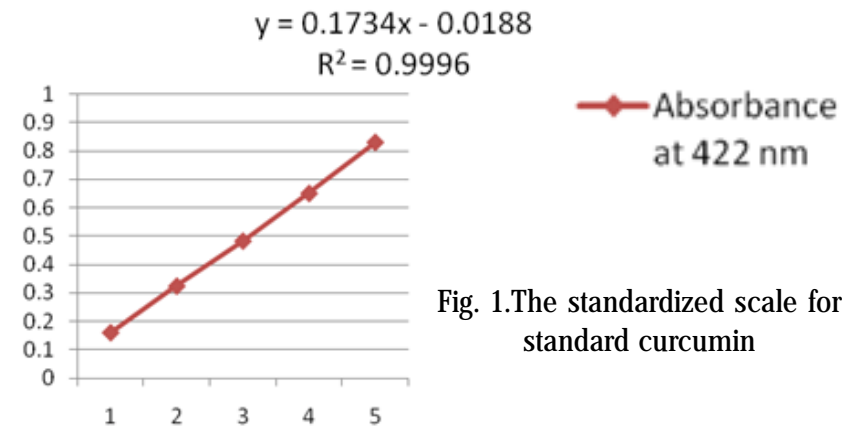

The equation of the direct line obtained in the standardized scale for standard curcumin is used in order to evaluate the curcumin concentration in the analyzed samples:

$$
\begin{aligned}
& y=0.1734 x-0.0188 \\
& x=\frac{y+0.0188}{0.01734} \\
& y=\text { absorbance } \\
& x=\text { standard curcumin concentration }
\end{aligned}
$$

$0.1 \mathrm{~mL}$ of the extract was introduced into the balloon of $100 \mathrm{~mL}$ of ethanol (it was used as a witness). The absorbance was measured at $422 \mathrm{~nm}$ wavelength with the help of the Spekol 11 spectrophotometer.

$$
\begin{aligned}
& y=0.215 \\
& y=\text { read absorbance } \\
& y=0.1734 x-0.0188 \\
& x=\frac{0.215+0.0188}{0.1734}=>x=1.348 \mu \mathrm{g}
\end{aligned}
$$

So from $0.1 \mathrm{~mL}$ extract we obtained $1.348 \mu \mathrm{g}$ and from $17 \mathrm{~mL}, 229.16 \mu \mathrm{g}$ curcumin. $100 \mathrm{~g}$ of turmeric powder has $2291.6 \mu \mathrm{g}$ of curcumin, meaning $2.2916 \mathrm{mg} \%$ curcumin. $10 \mathrm{~g}$ of turmeric has $0.22 \mathrm{~g}$ of curcumin and $100 \mathrm{~g}$ has 2.2 g curcumin.

Concerning the 3 ointments (presented in fig. 2) prepared in line with the technique described earlier, the results were as following: Ointment 1 featured a homogenous appearance and a semisolid consistency with a yelloworange color and a pH of 6 . The second one was also homogenous and semisolid, orange in color, with a pH of 6.5 and the third ointment was a translucid, hydroscopic, hydrophilic gel with a $\mathrm{pH}$ of 7 . All of them had the 
characteristic smell due to their components and were also compatible with the $\mathrm{pH}$ of the skin.

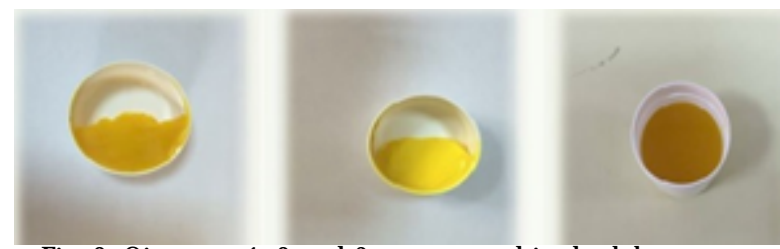

Fig. 2. Ointment 1, 2 and 3 as prepared in the laboratory.

By using the Ojeda-Arbussa method, the ointments capacity for adhesion/spreading was evaluated (table 3.)

Table 3

OINTMENTS 1, 2 AND 3 - ADHESION (SPREADING) CAPACITY (O) EDA-ARBUSSA METHOD)

\begin{tabular}{|l|l|l|l|}
\hline & Ointment 1 & Ointment 2 & Ointment 3 \\
\hline First plaque & $5 \mathrm{~cm}$ & $5.3 \mathrm{~cm}$ & $6.7 \mathrm{~cm}$ \\
\hline $\mathbf{1 0 0 \mathrm { g }}$ & $5.5 \mathrm{~cm}$ & $5.7 \mathrm{~cm}$ & $7.5 \mathrm{~cm}$ \\
\hline $\mathbf{2 0 0 \mathrm { g }}$ & $5.6 \mathrm{~cm}$ & $6 \mathrm{~cm}$ & $7.8 \mathrm{~cm}$ \\
\hline $\mathbf{3 0 0 \mathrm { g }}$ & $6 \mathrm{~cm}$ & $6.2 \mathrm{~cm}$ & $8.2 \mathrm{~cm}$ \\
\hline $\mathbf{4 0 0} \mathrm{g}$ & $6.4 \mathrm{~cm}$ & $6.5 \mathrm{~cm}$ & $8.2 \mathrm{~cm}$ \\
\hline $\mathbf{5 0 0 \mathrm { g }}$ & $6.5 \mathrm{~cm}$ & $6.7 \mathrm{~cm}$ & - \\
\hline
\end{tabular}
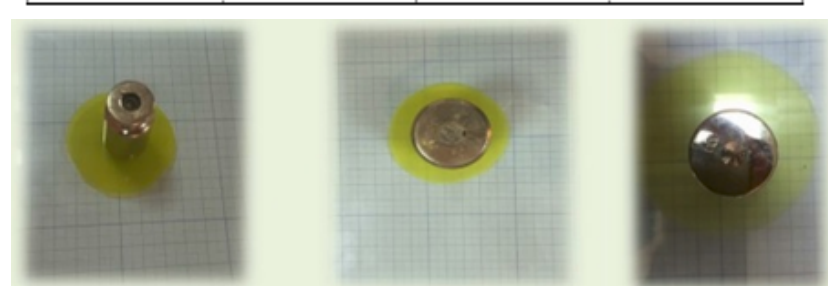

Fig. 3.Ointments 1, 2 and 3 - adhesion (spreading) capacity (OjedaArbussa method)

The results are pointing towards the fact that the adhesion/spreading capacity rises as the weights being added increase. As the surfaces become larger, the ointments have a higher capacity for adhesion/spreading. Data analysis reveals that Ointment 1has a lesser capacity for adhesion/spreading than Ointments 2 and 3; this is in direct link with their initial consistency. By adding the 500 $\mathrm{g}$ weight, Ointment 3 spread/adhered no more due to the fact that it is a gel.

The penetration of the ointment (meaning the degree of its consistency) was also evaluated and it established that the length of the product's penetration into the product's mass was $5 \mathrm{~cm}$ (from a maximum length of $10 \mathrm{~cm}$ ).

The stability of the 3 products was analyzed at 15 and 30 days from preparation and the characteristics evaluated were aspect, color and smell. Heatstability was unchanged for the 3 ointments at 15 days, but at 30 days it was modified for all. Cold stability was not modified for the products both at 15 and at 30 days. Stability to light was modified for all after 15 and 30 days, while dark stability was not changed in all cases. Room temperature stability was not changed for all ointments at 15 and 30 days. Thus curcumin is characterized as a photosensitive substance, being easily degraded by light.

The $\mathrm{pH}$ of the three ointments is shown in table 4.

\begin{tabular}{|l|l|}
\hline Ointment & $\mathbf{p H}$ \\
\hline $\mathbf{l}$ & 6 \\
\hline $\mathbf{2}$ & 6.5 \\
\hline $\mathbf{3}$ & $7^{-}$ \\
\hline Extract & $3^{-}$ \\
\hline
\end{tabular}

Table 4

pH OF THE PREPARED

PHARMACEUTICLAS

All of the experimental preparations have a $\mathrm{pH}$ compatible to that of the skin.

\section{Conclusions}

We have obtained a preparation that contains curcumin. Three ointments from the lipophilic and hydrophilic categories have been formulated. After turmeric extraction, an ethanol extract of curcumin was obtained, quantitatively titrated by the spectrophotometric method and obtaining a concentration of $2.2 \mathrm{~g} \%$ of curcumin.

After organoleptic analyses of the 3 ointments, the following observations were made: they have a characteristic aspect of the components and a specific smell. Their pH was in between the interval imposed by the Romanian Farmacopeea10th Edition. By verifying their stability we concluded that they are cold-stable, darkstable and room temperature-stable. These will be kept in tightly sealed recipients, at room temperature, safe from light and with a validity term of 3 to 5 months.

The therapeutic potential of curcumin is immense and there is data to support this statement. It may also be of interest to further research the prophylactic or healing effects on pigmented skin conditions, cutaneous and nevus photo protection (in order to prevent the Koebner phenomena), cancer or autoimmune disorders, as well as the possible use in pregnancy (having the patients' informed consent) both for curcumin and for other natural extracts (indigo naturalis for example). [43-59] In order for this to be brought to light further studies must be done in the future with the help of our method for obtaining curcumin-based ointment.

\section{References}

1.DI NARDO,V.,GIANFALDONI, S.,TCHERNEV,G., -Use of Curcumin in Psoriasis, Open Access, Maced J Med Sci. https://doi.org/10.3889/ oamjms.2018.055

2.CHATTOPADHYAY,I., BISWAS,K., BANDYOPADHYAY,U., BANERJEE,R.K., - Turmeric and curcumin: Biological actions and medicinal applications, Current science, vol. 87, no. 1, 10 J uly 2004 3.SUBASH C. GUPTA, GORKEMKISMALI, BHARAT B. AGGARWAL Curcumin, a component of turmeric: From farm, to pharmacy, Biofactors. 2013 J an-Feb;39(1):2-13. doi 10.1002/biof.1079. Epub 2013 Jan 22

4.NEMAT J . ABDULBAQI, BATOL I. DHEEB, RIZW ANIRSHAD - Expression of Biotransformation and Antioxidant Genes in the Liver of Albino Mice after Exposure to Aflatoxin B1 and an Antioxidant Sourced from Turmeric (Curcuma longa), J ordan Journal of Biological Sciences, Volume 11, Number 1,March 2018, ISSN 1995-6673, Pages 93 - 98

5.MANE RP, KSHIRSAGAR RB, SAWATE AR, PATIL BM AND KALE RG Studies on evaluation of physicochemical and nutritional properties of fresh turmeric rhizome, Journal of Pharmacognosy and Phytochemistry 2018; 7(2): 2895-2897

6.SIMEN ANTONSEN, RUNA OSTBY, YNGVE STENSTROM - Naturally Occurring Cyclobutanes: Their Biological Signiûcance and Synthesis, Studies in Natural Products Chemistry, Volume 57, 2018, pg. 179-202 7.KULKARNI et al. - The Perception of Dermatologists towards the Outcome of Ayurvedic Therapy for Psoriasis, J ClinExpDermatol Res 2018, 9:5, DOI: 10.4172/2155-9554.1000465

8.SAHDEO PRASAD, AMIT K. TYAGI, BHARAT B. AGGARWAL - Recent Developments in Delivery, Bioavailability, Absorption and Metabolism of Curcumin: the Golden Pigment from Golden Spice, Cancer Res Treat. 2014;46(1):2-18

9.GHEORGHE I,TATU AL,LUPU I, THAMER O ,COTAR AI,PIRCALABIORU GG,POPA M,CRISTEA VC,LAZAR V,CHIFIRIUC MC. Molecular characterization of virulence and resistance features in Staphylococcus aureus clinical strains isolated from cutaneous lesions in patients with drug adverse reactions. Rom Biotech Lett. 2017;22(1):12321-27

10.TATU AL, MEREZEANU N, PANTEA O, GHEORGHE I, POPA M, BANU 0 , CRISTEA VC, CHIFIRIUC MC, LAZAR V, MARUTESCU L. Resistance features of Pseudomonas aeruginosa strains isolated from patients with infectious complications of cardiovascular surgery.) Biointerface Res. Appl. Chem.2017; 7(2):2004-2008

11.PRICOP R,CRISTEA VC, GHEORGHE I, TATU AL, MIHAESCU G,CHIFIRIUC MC.Matrix-assisted laser desorption/ionization time-offlight mas spectrometry (MALDI-TOF MS) reveals the anaerobic Slakia exigua as unique etiology of a dental abscess. ) Biointerface Res. Appl. Chem.2017; 7( 2):1995-1997 
12.TATU AL, IONESCU MA, CLATICI VG, et al. Bacillus cereus strain isolated from Demodex folliculorum in patients with topical steroidinduced rosaceiform facial dermatitis.An Bras Dermatol. 2016;91:67678

13.TATU AL-Topical Steroid Induced Facial Rosaceiform Dermatitis. Acta Endo (Buc) 2016 12: 232-233

14.TATU AL, IONESCU MA, NWABUDIKE LC. Contact allergy to topical mometasone furoate confirmed by rechallenge and patch test. Am J Ther. 2018;25(4):e497-e498

15.TATU AL, NWABUDIKE LC. Bullous Reactions Associated W ith COX2 Inhibitors Am J Ther. 2017;24(4):e477-e480

16.TATU AL, NWABUDIKE LC. Metoprolol-associated onset of psoriatic arthropathy. Am J Ther.2017;24(3);e370-e371

17.NWABUDIKE, L.C. ,TATU, A.L. , Response to - Chronic exposure to tetracyclines and subsequent diagnosis for non-melanoma skin cancer in a large Mid-Western US population. J Eur Acad Dermatol Venereol. 2018;32(4):e 159

18.TATU AL,CIOBOTARU OR, MIULESCU M,BUZIA OD,ELISEI AM,MARDARE N,DIACONU C, ROBU S, NWABUDIKE LC.Hydrochlorothiazide: Chemical Structure, Therapeutic, Phototoxic and Carcinogenetic Effects in Dermatology. Rev.Chim.(Bucharest), 69, no.8, 2018, p.2110-2114

19.TATU AL. Clinico dermoscopic correlations observed in a rosacea group of patients J Am Acad Dermatol 2016;74(5)Suppl 1:AB 104

20.Tatu AL, Clãtici V, Some correlations between the clinical and dermoscopic features of steroid induced facial dermatitis. J Am Acad Dermatol 2015.72;(5)Suppl 1:AB91

21.TATU AL,NWABUDIKE LC.The Treatment Options of Male Genital Lichen Sclerosus et Atrophicus Short Title for a Running Head: Treatments of Genital Lichen Sclerosus .Proceedings Of The 14th National Congress Of Urogynecology And The National Conference Of The Romanian Association For The Study Of Pain .2017: 262-264 22.NWABUDIKE LC, ELISEI AM, BUZIA OD, MIULESCU M, TATU AL. Statins. A Review on Structural Perspectives, Adverse Reactions and Relations with Non-melanoma Skin Cancer Rev.Chim.(Bucharest), 69, no.9, 2018, p.2557-2562

23.TATU AL. Trichoscopic patterns of Adult Alopecia Areata.J Invest Dermatol.2010.130;Suppl 2:S57

24.TATU AL,NWABUDIKE LC. Male genital lichen sclerosus-a permanenttherapeutic challenge.J Am Acad Dermatol.2018;79(3)Supplm 1,AB185

25.CLATICI VC, GEORGESCU 0, DRAGANITA AMV, TATU AL, FICA S. Milk and Insulin Growth Factor 1 (IGF1) - Implication in Acne and General Health.Rom Biotech Lett. 2015;20(1):10013-25

26.BRANISTEANU DE, PINTILIE A, DIMITRIU A,CERBU A,CIOBANU D,OANTA A,TATU AL. Clinical, laboratory and therapeutic profile of lichen planus. The Medical-Surgical J ournal $2017 ; 121(1): 25-32$

27.TATU AL, CLATICI V, CRISTEA V. Isolation of Bacillus simplex strain from Demodex folliculorum and observations about Demodicosis spinulosa. Clin Exp Dermatol. 2016 ;41:818-205.

28.TATU AL, IONESCU M A, CRISTEA V C. Demodex folliculorum associated Bacillus pumilus in lesional areas in rosacea. Indian J Dermatol Venereol Leprol 2017;83:610-1

29.TATU AL, NWABUDIKE LC. Reply to: KUBIAK K and al. Endosymbiosis and its significance in dermatology.J Eur Acad Dermatol Venereol 2018:32(9):e346-e347

30.TATU AL, CLATICI VG, NWABUDIKE LC. Rosacea-like demodicosis (but not primary demodicosis) and papulopustular rosacea may be two phenotypes of the same disease - a microbioma, therapeutic and diagnostic tools perspective. J Eur Acad Dermatol Venereol. 2018 J un 29. doi: 10.1111/jdv.15166. [Epub ahead of print]

31.TATU AL.Nasal spinulosis.J Cutan Med Surg.2017;21(3);252

32.TATU AL,CRISTEA VC. Pityriasis Folliculorum of the BackThoracic Area: Pityrosporum, Keratin Plugs, or Demodex Involved? J Cutan Med Surg. 2017;21(5):441

33.TATU AL, CRISTEA VC. Unilateral Blepharitis With Fine Follicular Scaling .J Cutan Med Surg. 2017;21(5):442.

34.TATU AL. Clinico dermoscopic correlations observed in a rosacea group of patients J Am Acad Dermatol 2016;74(5)Suppl 1:AB 104

35.DRAGANESCU M, IANCU A.V., FIRESCU D, DUMITRIU B.O., DIACONU C, REBEGEA L, Trends in antimicrobials consumption and antimicrobial resistance in an infectious diseases hospital from the south-eastern ,Farmacia,2016,Vol 64,5,pag.770-774
36.DRAGANESCU M,BAROIU N, BAROIU L,DIACONU C,DUMITRIU B.O.,Efficeint administration of human albumin in clostridiumDifficile infection, Rev.chim.(Bucharest),68,no. 3 , 2017, p.602-604

37.DUMITRIU BUZIA, O.,Tehnologiefarmaceuticã II, Galai, Romania, Ed. Zigotto, 2014, pg219-251, ISBN: 978-606-669-101-7

38.0. D. Buzia, N. Mardare, Tehnologiefarmaceuticã II, Galai, Romania, Ed. Zigotto, 2013; 57-108,ISBN:978-606-669-021-8.

39.DUMITRIU BUZIA, O., TehnologieFarmaceuticã, note de curs, anul IV, sem. I, cursurile VII-VIII, 2016.

40.POPOVICI I., LUPULEASA D., Tehnologiefarmaceuticã, Vol. 3, România, Ed. Polirom, 2009; 669-674, ISBN: 978-973-46-1264-2

41.RAICU S., CALIN G., IVASCU V., LEUCUTA S., STANESCU V., Farmacopeearomânã, ediia a X-a, Bucure'ti, România, Ed. Medicala, 2014; 952, ISBN: 978-973-39-0662-3.

42.MARINESCU SA, TATU AL, MIHAI IR, GIUGLEA C. Correlations between clinics, dermoscopy and histopathology in a female with two dermatofibromas - a case report.Rom J Morphol Embryol. 2016;57(1):323-6

43.TATU AL.Black Nodule on the Forearm. J Cutan Med Surg 2017.21(2);157

44.TATU AL- Umbilicated blue black lesion on the lateral thorax J Cutan Med Surg2017.21(3);252

45.TATU AL.Skin tags and pregnancy Australas J Dermatol.2010;51Suppl S1:A42

46.TATU AL The skin and nevi pigmentation during pregnancy. J Am Acad Dermatol.2012.66;(2)Suppl 1:AB 148

47.TATU AL. Dermoscopic structural changes of nevi during pregnancy related to location.J Am Acad Dermatol.2011.64;(2),Suppl1:AB75

48.TATU AL, NWABUDIKE LC. Reply to Happle R. And al. Koebner's sheep in Wolf's clothing: does the isotopic response exist as a distinct phenomenon?. J Eur Acad Dermatol Venereol.2018;32(8):e336-337 49.NWABUDIKE, L.C. AND TATU, A.L Reply to Gambichler T et al.: Altered epigenetic pathways and cell cycle dysregulation in healthy appearing skin of patients with koebnerized squamous cell carcinomas following skin surgery. J Eur Acad Dermatol Venereol 201814 DOI: 10.1111/jdv.15084,Epub ahead of print

50.TATU AL,IONESCU MA. Multiple autoimmune syndrome type IIIthyroiditis,vitiligo and alopecia areata .Acta Endo (Buc)2017, 13 (1): 124-125

51.MIHAILA B, DINICA RM, TATU AL , DUMITRIU BUZIA O., New insights in vitiligo treatments using bioactive compounds from Piper nigrum. Exp Ther Med.2018. doi.org/10.3892/etm.2018.6977

52.NWABUDIKE LC, TATU AL. Magistral prescription with silver nitrate and Peru Balsam in difficult to heal diabetic foot ulcers Am J Ther. . 2018;25(6): e679-e680

53.ROGOZEA LM , DIACONESCU DE, DINU EA; et al. Bioethical dilemmas in using animal in medical research. Challenges and opportunities.Rom J MorpholEmbryol2015; 56(3): 1227-31

54.PURCARU D, PREDA A, POPA D, MOGA MA, ROGOZEA L. Informed Consent: How Much Awareness Is There? PLoS One. 2014;9(10):e110139 55.DUMITRIU BUZIA OD, FASIE V, MARDARE N, DIACONU C,GURAU G,TATU AL. Formulation, preparation, physico-chimical analysis,microbiological peculiarities and therapeutic challenges of extractive solution Kombucha.Rev.Chim.(Bucharest), 69, no.3, 2018, p.720-724

56.DUMITRIU BUZIA, O., MARDARE N,FLOREA A,DIACONU C,DINICA RM, TATU AL.Formulation and Preparation of Pharmaceuticals with Anti-rheumatic Effect using the Active Principles of Capsicum Annuum and Piper Nigrum. Rev.Chim.(Bucharest), 69, no.10, 2018, p.28542857

57.A. CARESSE GAMRET, ALEXANDRA PRICE, RAYMOND M. FERTIG et al. - Complementary and Alternative Medicine Therapies for Psoriasis, JAMA Dermatol. 2018;154(11):1330-1337

58.DUMITRIU BUZIA O., MARDARE N,FLOREA A,DIACONU C,DINICA RM, TATU AL.Formulation and Preparation of Pharmaceuticals with Anti-rheumatic Effect using the Active Principles of Capsicum Annuum and Piper Nigrum. Rev.Chim.(Bucharest), 69, no.10, 2018, p.28542857

59.ROBU S., CHESARU B.I, DIACONU C., DUMITRIU B.O., TUTUNARU D, STANESCU U, LISA E.L.,Lavandula hybrida: microscopic characterization and the evaluation of the essential oil Farmacia, 2016, vol. 64, 6.914-917 